\title{
Experimental elucidation of an antimycobacterial bacteriocin produced by ethnomedicinal plant-derived Bacillus subtilis (MK733983)
}

\author{
S. Santhi Sudha ${ }^{1} \cdot$ V. Aranganathan ${ }^{1}$ (i)
}

Received: 22 August 2020 / Revised: 24 November 2020 / Accepted: 27 December 2020 / Published online: 5 February 2021

(c) The Author(s), under exclusive licence to Springer-Verlag GmbH, DE part of Springer Nature 2021

\begin{abstract}
A bacteriocin from Bacillus subtilis (MK733983) originated from ethnomedicinal plant was purified using Preparative RP-HPLC. The HPLC fraction eluted with 65\% acetonitrile showed the highest antimicrobial activity with Mycobacterium smegmatis as an indicator. Its specific activity and purification fold increased by $70.5 \%$ and $44 \%$, respectively, compared to the crude bacteriocin. The bacteriocin showed stability over a wide range of $\mathrm{pH}(3.0-8.0)$ and preservation $\left(-20{ }^{\circ} \mathrm{C}\right.$ and $4{ }^{\circ} \mathrm{C}$ ), also thermal stability up to $80^{\circ} \mathrm{C}$ for $20 \mathrm{~min}$. Its proteinaceous nature was confirmed with complete loss of activity on its treatment with Trypsin, Proteinase K, and $\alpha$-Chymotrypsin. Nevertheless, the bacteriocin retained up to $45 \%$ activity with Papainase treatment and was unaffected by salivary Amylase. It maintained $\sim 95 \%$ activity on UV exposure up to $3 \mathrm{~h}$ and its activity was augmented by ethyl alcohol and metal ions like $\mathrm{Fe}^{2+}$ and $\mathrm{Mn}^{2+}$. Most of the common organic solvents, general surfactants, preservatives, and detergents like Sulfobetaine-14, Deoxy-cholic-acid did not affect the bacteriocin's action. Its molecular weight was estimated to be 3.4KDa by LC-ESI-MS/MS analysis. The bacteriocin is non-hemolytic and exhibited a broad inhibition spectrum with standard strains of Staphylococcus aureus, Pseudomonas aeruginosa, Klebsiella pneumoniae, Escherichia coli and Chromobacterium violaceum with MICs ranging $0.225 \pm 0.02-0.55 \pm 0.05 \mathrm{mg} / \mathrm{mL}$. Scanning Electron Microscopy showed cell annihilation with pores in cell membranes of $S$. aureus and $P$. aeruginosa treated with the bacteriocin, implicating bactericidal mode of action. These promising results suggest that the bacteriocin is significant and has wide-ranging application prospects.
\end{abstract}

Keywords Bacteriocin $\cdot$ Bacillus subtilis $\cdot$ Mycobacterium smegmatis $\cdot$ Broad inhibition spectrum $\cdot$ LC-ESI-MS/MS

\section{Introduction}

Antimicrobial resistance (AMR) is one of the ecological adaptations among microbes with their competitors either for resources or existence. Over the past decades, a widespread use of antibiotics has drastically increased the number of antibiotic-resistant microbes. These resistant microbes assimilate multifarious mechanisms

Communicated by Erko Stackebrandt.

V. Aranganathan

v.aranganathan@jainuniversity.ac.in

S. Santhi Sudha

sushanti4all@yahoo.com

1 Department of Biochemistry, Jain (Deemed To-Be) University, 18/3, 3rd Block, 9th Main Rd, Jayanagar, Bangalore, Karnataka 560011, India to survive various impacts of antibiotics. This is a dangerously evolving situation and a grave health hazard threatening various existing medical practices, global health, and economy. On the other hand, scarcity of novel antimicrobials in recent years is aggravating the situation (WHO 2020; Wolcott and Ehrlich 2008). Some of the common pathogens such as Escherichia coli, Staphylococcus aureus, Pseudomonas aeruginosa and coagulase-negative staphylococci cause up to $65 \%$ cases of bacteremia. These pathogenic ailments are not only amounting to $98.2 \%$ of overall systemic infections but are developing resistance to numerous antibiotics at a frightening pace (Sohail et al. 2015). Older infections such as Tuberculosis (TB) yet remain to be the worst communicable diseases in humans with high death rates. WHO estimated nearly 1.7 million TB deaths and 10.4 million newly infected cases in 2016. Of these occurrences, new rifampicin-resistant cases were 600,000 and 
490,000 confirmed multidrug-resistant TB (MDR-TB) (Sivaraj et al. 2018). Even with the escalating complexities of TB and other infections, efficacious drugs have not been discovered for the past 40 years except for a novel TB drug, bedaquiline approved in 2012. Considering the whole ordeal, WHO (2017) advocates judicious antibiotic use and instigated an action plan on AMR to guide novel discoveries and development of new antibiotics. The WHO has disclosed a Priority Pathogens List (PPL) that emphasize on pathogens needing critical innovations and advancement of treatments and vaccines.

Antimicrobial peptides (AMPs) are also known as host defense peptides (HDPs) and they are emerging as potential therapeutic alternatives to antibiotics. They are relatively small, heterogenous, amphipathic or predominantly cationic peptides with an ability to inhibit or eradicate planktonic microbes. They have distinctive attributes and diverse kill mechanisms with precise selective toxicity against bacteria, fungi, viruses, and parasites. Each AMP is unique with its specific discriminatory characteristics and multidimensional properties like flexibility, synergistic potency with various antibiotics and conventional drugs, neutralization of endotoxins with low minimum inhibitory concentrations (MICs), inhibition or eradication of established biofilms, significant anti-viral and anti-cancerous properties, broad-spectrum inhibition of multi drug resistant (MDR) microbes, immunomodulation and others. Such valuable properties are awarding attention to AMPs as exploration hot spots. Many studies have validated its applications in Medicine, Agriculture, Animal Husbandry, Aquaculture and Bio-preservation among others (Naafs et al. 2018; Gutsmann 2016).

Several AMPs have been isolated from Bacillus species like coagulin, tochicin, subtilin, and megasin (Park et al. 2002). Bacillus subtilis strains are well-known to produce many bacteriocins with varied functions depending on their ecological spaces, allocation of resources and entrants, yet bacteriocins from these strains are less explored (Ramya et al. 2014). The objective of this study was to purify and characterize a potential bacteriocin from an ethnomedicinal plant originated strain of $B$. subtilis (MK733983). Furthermore, its inhibition spectrum, hemolytic activity and mechanism of action were also delineated.

\section{Materials and methods}

\section{Chemicals and materials}

All the chemicals were purchased from SD Fine-Chem Ltd (India), HIMEDIA and Thermo Fisher Scientific. Polyethersulfone membrane syringe filter-pore size $0.22 \mu \mathrm{m}$ (Merck),
SEP-PACK C18 cartridge (Flinn Scientific) and goat blood was procured from the local butcher shop.

\section{Indicator microorganisms (IMOs)}

Mycobacterium smegmatis ( $\mathrm{MC}^{2}-155$ wild type) (ATCC 607)-MS, Staphylococcus aureus (MTCC 737)-SA, Pseudomonas aeruginosa (MTCC 3541)-PA, Klebsiella pneumoniae (ATCC 700,721)-KP, Escherichia coli (ATCC 8739)-EC and Chromobacterium violaceum (MTCC 2656)-CV.

\section{Enzymes}

Trypsin (T-8918; Sigma), Proteinase K (P-2308; Sigma), Papain (GRM058-HIMEDIA), $\alpha$-Chymotrypsin (RM801HIMEDIA) and Salivary amylase (Human Saliva in 1: 9 of $0.85 \%$ saline solution).

\section{Bacteriocin activity assay}

Antimicrobial potential of the bacteriocin was evaluated using Spot-on-lawn or well diffusion assays, these assays were performed twice in triplicates with indicator organisms (SA, MS, PA, KP, EC \& CV) (Balouiri et al. 2016; Tagg and McGiven 1971). $30 \mu \mathrm{L}$ of the purified bacteriocin was dissolved in DMSO were loaded into each $6 \mathrm{~mm}$ wide wells made in suitable agar plates, pre-swabbed with $100 \mu \mathrm{L}$ indicator inoculum, then these plates were incubated at $37{ }^{\circ} \mathrm{C}$ for $24 \mathrm{~h}$. C. violaceum was sensitive to $1 \% \mathrm{DMSO}$, therefore, $0.5 \%$ DMSO was used as blank or negative control and $1 \%$ DMSO was taken as a blank or negative control for all other IMOs in this study. Anti-bacterial activity was determined based on its potential inhibitory zone $(\mathrm{mm})$ against indicator organisms (Cita et al. 2017). Activity was calculated as $a^{b} \times 100$, where ' $a$ ' is the dilution factor and ' $b$ ' is the final dilution factor that produced a minimum inhibition zone of $2 \mathrm{~mm}$.

\section{Purification and analysis}

The proteins were estimated according to Lowry et al. (1951) and the bacteriocin's specific activity was evaluated following Lee and Chang (2018) protocol. The Bacteriocin, an antimicrobial peptide was purified to its homogeneity using Preparative RP-HPLC as described by Anand et al. (2005) and Lee and Chang (2018) with minor modifications. Further, the sample was dissolved in methanol $(1 \% \mathrm{v} / \mathrm{v})$ and passed through C18 SEP-PACK for better extraction and fractionation of the desired low molecular weight antimicrobial peptides. The dried concentrates were dissolved in 
$50 \%$ acetonitrile $(1 \mathrm{mg} / \mathrm{mL})$ and ultra-filtrated with $0.22 \mu \mathrm{m}$ membrane filter. Followed by a separating technique using recycling preparative LC-120AD (228-45,000-4B) HPLC system with reverse-phase C-18 (VYDAC) column $(10 \times 250 \mathrm{~mm})$ connected to Shimadzu SPD-6AV UV-VIS detectors (200 \& 254) nm. The first injection on RP-HPLC used a water-acetonitrile gradient $(50-50 \%)$ at a flow rate of $1 \mathrm{ml}$ per min and eluents were collected every $10 \mathrm{~min}$ for $50 \mathrm{~min}$. These fractions were concentrated and resuspended in $10 \mathrm{mM}$ Tris $-\mathrm{HCl}(\mathrm{pH} 7)$ and were tested for antibacterial activity. The fraction that showed the highest antimicrobial activity was re-run with two different elution gradients of water-acetonitrile (60-40\%) and (40-65\%). The flow rate was maintained at $1 \mathrm{ml}$ per min, that was collected every $20 \mathrm{~min}$ for an hour and were tested as mentioned above. The fraction that showed the best antimicrobial activity was further analyzed by LC-ESI-MS/MS (Malini and Savitha 2012).

\section{Invitro Bio-physiochemical characterization}

\section{Effect of temperature, $\mathrm{pH}$, hydrolytic enzymes, and UV rays}

The effect of heat on the bacteriocin (AMP) was evaluated by its incubation under moist heat treatment from $40-121{ }^{\circ} \mathrm{C}$ by $10{ }^{\circ} \mathrm{C}$ rise for $20 \mathrm{~min}$. Its preservation capacity was tested for 120 days (30 day interval) at $\left(-20^{\circ} \mathrm{C}\right.$ and $\left.4{ }^{\circ} \mathrm{C}\right)$ and at room temp $\left(25-28^{\circ} \mathrm{C}\right)$ for 5 days ( $24 \mathrm{~h}$ interval).

The $\mathrm{pH}$ of the bacteriocin was adjusted to 3-10 (interval of 1) using sterile $5 \mathrm{~mol} / \mathrm{mL} \mathrm{NaOH}$ or $\mathrm{HCl}$ and were maintained at corresponding $\mathrm{pH}$ for $20 \mathrm{~min}$ (Ge et al. 2016), it was then resuspended in $10 \mathrm{mM}$ Tris- $\mathrm{HCl}(\mathrm{pH} 7)$ and tested for antibacterial activity.

The effect of hydrolytic enzymes was evaluated by taking each in 1:5 ratio of bacteriocin to Trypsin ( $\mathrm{pH} \mathrm{8.0),} \mathrm{Protein-}$ ase $\mathrm{K}(\mathrm{pH} 7.5), \alpha$-Chymotrypsin ( $\mathrm{pH} 7.8)$, Papainase $(\mathrm{pH}$ 7.0) and Salivary amylase (pH 7.0) were incubated at $37^{\circ} \mathrm{C}$ for $24 \mathrm{~h}$.

The effect of UV rays on the bacteriocin for up to $6 \mathrm{~h}$ (60 min interval) was also evaluated. Further, the samples that were unexposed to heat, enzymes, $\mathrm{pH}$ and UV were taken as positive control and LB broth was taken as a negative control or Blank. Residual bacteriocin activity of all the samples was tested and evaluated for antimicrobial activity based on the ratio of inhibitory activity of treated to untreated. Antimicrobial activity was assessed by the well diffusion assays (IMO- M. smegmatis) and these were conducted in triplicates and their average values with the standard deviations were reported.
Effect of organic solvents, salt, surfactants, preservatives, and metal ions

$30 \mu \mathrm{L}$ of the bacteriocin $(1 \mathrm{mg} / \mathrm{mL})$ was incubated for an hour with each $10 \%$ w/v of methanol, ethanol, butanol, acetone, benzene, propanol, DMSO, xylol and chloroform at $25^{\circ} \mathrm{C}$ to examine their effect. The response of different concentrations of sodium chloride $(2-12 \%)$ on the bacteriocin was evaluated (Zhang et al. 2018). Effect of surfactants such as sodium dodecyl sulphate $(1 \mathrm{mg} / \mathrm{mL})$, triton X-100 $(1 \% \mathrm{v} / \mathrm{v})$, tween $20,80(10 \% \mathrm{v} / \mathrm{v})$, sodium deoxycholate $(1 \mathrm{mg} / \mathrm{mL})$ and sulfobetaine $14(1 \mathrm{mg} / \mathrm{mL})$ on the antimicrobial peptide was analyzed as described by Bizani and Brandelli (2002). It was also examined to validate its outcome with certain common protein denaturing agents scuh as trichloroacetic acid (TCA $10 \% \mathrm{v} / \mathrm{v}$ ), sodium bicarbonate $(12 \% \mathrm{w} / \mathrm{v})$, sodium sulphate $(12 \% \mathrm{w} / \mathrm{v}), \beta$ mercaptoethanol $(10 \% \mathrm{v} / \mathrm{v})$, urea $(1 \mathrm{mg} / \mathrm{mL})$, preservatives like EDTA $(10 \mathrm{mmol} / \mathrm{L})$, sodium citrate $(1 \mathrm{mg} / \mathrm{mL})$, catalysts such as sodium tungstate $(1 \mathrm{mg} / \mathrm{mL})$ and metal ions like $\mathrm{KCl}, \mathrm{CaCl}_{2}$, $\mathrm{FeSO}_{4}, \mathrm{ZnSO}_{4}, \mathrm{CuCl}_{2}, \mathrm{MgSO}_{4}$ and $\mathrm{MnSO}_{4}(2.0 \mathrm{mmol} / \mathrm{L})$. Residual bacteriocin activity was measured as described earlier, all experiments were conducted in triplicates and average values with standard deviations were calculated.

\section{Bioassays}

\section{Hemolytic assay}

Hemolytic activity on the bacteriocin was investigated according to the methods described by Wu et al. (2020), Afsar et al. (2016) and Soto (2014) with minimal variations. Fresh pellet of erythrocytes from Goat blood was adjusted to a concentration of $5 \%$ in saline solution. $100 \mu \mathrm{L}$ of saline solution was added to all the wells (1-12) of a microplate and the well 11 is taken as a negative control. $100 \mu \mathrm{L}$ of the bacteriocin (100 $\mu \mathrm{g}, 250 \mu \mathrm{g}, 500 \mu \mathrm{g}$ and $1 \mathrm{mg} / \mathrm{ml}$ ) was added to each of the first wells followed by twofold dilutions performed till 10th well, well 12 containing $100 \mu \mathrm{L}$ of $1 \%$ Triton-X 100 as a positive control. Then $100 \mu \mathrm{L}$ of $5 \%$ blood was added to the wells except well 11 . Plate was incubated at $37^{\circ} \mathrm{C}$ for an hour and $70 \mu \mathrm{L}$ of supernatants from each well were collected into a new microplate to avoid any sediment from hemolysis. The samples were measured absorbance at $490 \mathrm{~nm}$ using ELISA reader (Lisa Plus Plate Reader, Rapid Diagnostics, India). The assay was carried out twice in duplicates, and the percentage of hemolysis was calculated as follows,

$$
\begin{aligned}
& \text { Haemolysis } \%=\frac{\text { OD of Bacterioicn }- \text { OD of }(-v e) \text { Control }}{\text { OD of }(+v e) \text { Control }} \\
& - \text { OD of }(-v e) \text { Control } \times 100
\end{aligned}
$$


Inhibition spectrum and minimal inhibitory concentrations (MICs)

The IMO's were taken in an inoculum size of $10^{6} \mathrm{CFU} / \mathrm{mL}$, measured at $\mathrm{A}_{600}$ for antimicrobial assays in their suitable growth conditions. $M$. smegmatis, $S$. aureus, $P$. aeruginosa and $C$. violaceum were grown in LB (Luria-Bertani) media, and $K$. pneumoniae, E. coli on MH (Muller-Hinton) Media at $35^{\circ} \mathrm{C}$ for $24 \mathrm{~h} .20 \mu \mathrm{L}(\sim 2 \mathrm{mg})$ and $40 \mu \mathrm{L}(\sim 4 \mathrm{mg})$ of the purified AMP was placed in the wells of media overlaid with $100 \mu \mathrm{L}$ of gram positive and negative IMO's, respectively. Plates were incubated at $37^{\circ} \mathrm{C}$ for $24 \mathrm{~h}$ and the antimicrobial activity was evaluated along with MIC values as described by Santhi and Aranganathan (2019).

\section{Mode of action (MOA)}

Morphological Changes on treatment with bacteriocin were evaluated according to the methods described by Wu et al. (2020) and Park et al. (2002) with slight variations. S. aureus, a gram-positive and P. aeruginosa, gram-negative IMO were grown in standard LB broth, incubated at $37{ }^{\circ} \mathrm{C}$ for $24 \mathrm{~h}$. The indicator cells (probably in stationary phase) were suspended in saline and treated with the same volume of the bacteriocin $(1 \mathrm{mg} / \mathrm{mL})$, the untreated cells were taken as control. After incubation (3-6 h at $37{ }^{\circ} \mathrm{C}$ ), cells were thoroughly washed with phosphate buffer (pH7.4), resuspended in $2.5 \%$ glutaraldehyde and were dehydrated via gradual ethanol gradient (10-100\%). Dehydrated samples were freeze-dried, gold coated and observed using a Field-emission scanning electron microscopy (FESEM) with dual-beam focused ion-beam (FIB), EDS and monochrometer (MonoCL) (Indian Institute of Science, Bengaluru).

\section{Statistical analysis}

All experimental results were expressed as means \pm standard error of the standard deviation (SD), the significant differences were examined using Microsoft Excel [Microsoft 365 MSO (16.0.12827.20200) 32-bit]. Relative Percentages and residual activity were calculated in comparison to the Positive control values of the experiments performed.

\section{Results}

\section{Purification and analysis}

Among all fractions from preparative RP-HPLC of C18 SEP-PAK purified sample eluted with $50 \%$ Acetonitrile, fraction 1.4 collected at 30-40 min shows the highest zone of inhibition (Fig. 1). On the re-run, fraction 1.4 with $40 \%$ acetonitrile noted as sub fractions 1.4 .1 to 1.4 .3 , the fraction that was collected between $20-40 \mathrm{~min}, 1.4 .2$ alone showed antimicrobial activity (Fig. 2). However, the same fraction (1.4) when re-run with $65 \%$ acetonitrile noted as sub fractions 1.4 .1a to $1.4 .3 \mathrm{a}$, the fraction that was collected between 20-40 min, 1.4.2a showed highest antimicrobial activity (Fig. 3). This active compound was estimated to have $3402.87 \mathrm{~m} / \mathrm{z}$ ions at an intensity between $(1.8 \mathrm{e}+3)-(1.9 \mathrm{e}+3)$ by LC-ESI-MS/MS analysis (Fig. 4).

\section{$<$ Chromatogram $>$ \\ $\mathrm{mV}$}

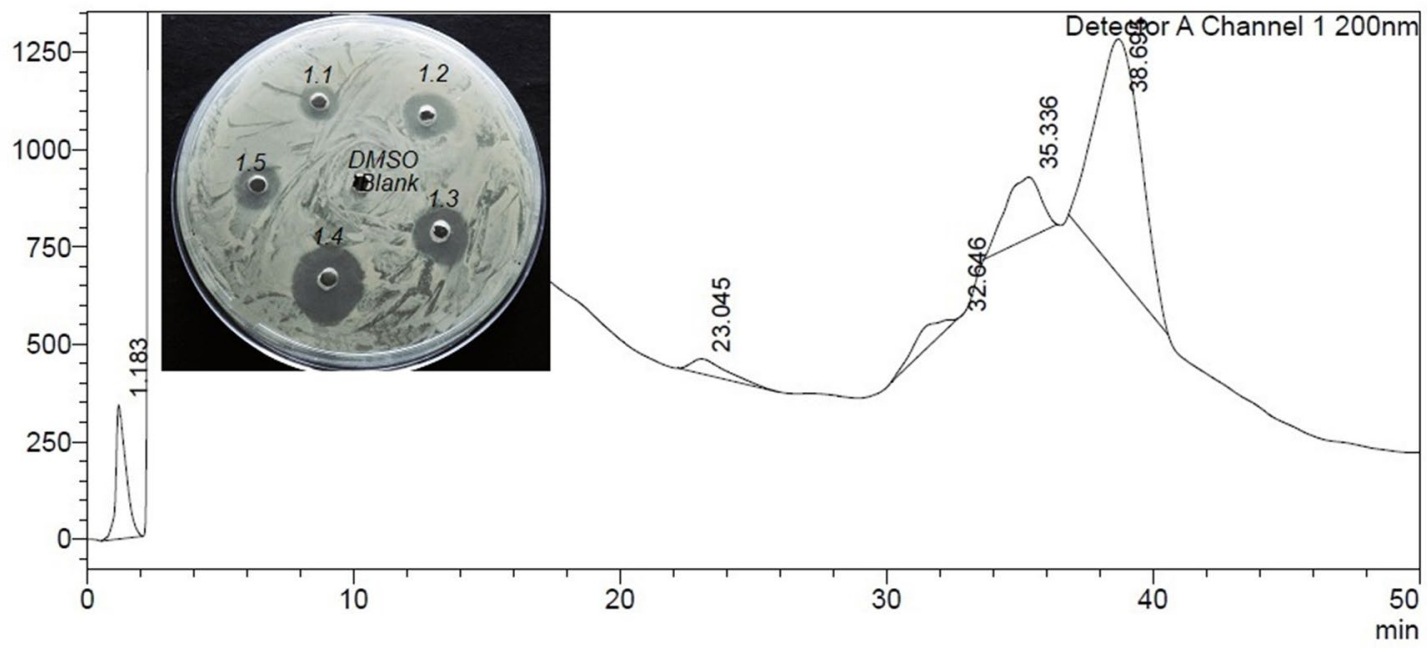

Fig. 1 Chromatogram of preparative RP-HPLC of C18 SEP-PAK purified sample shows highest zone of inhibition 


\section{$<$ Chromatogram $>$}

$\mathrm{mV}$

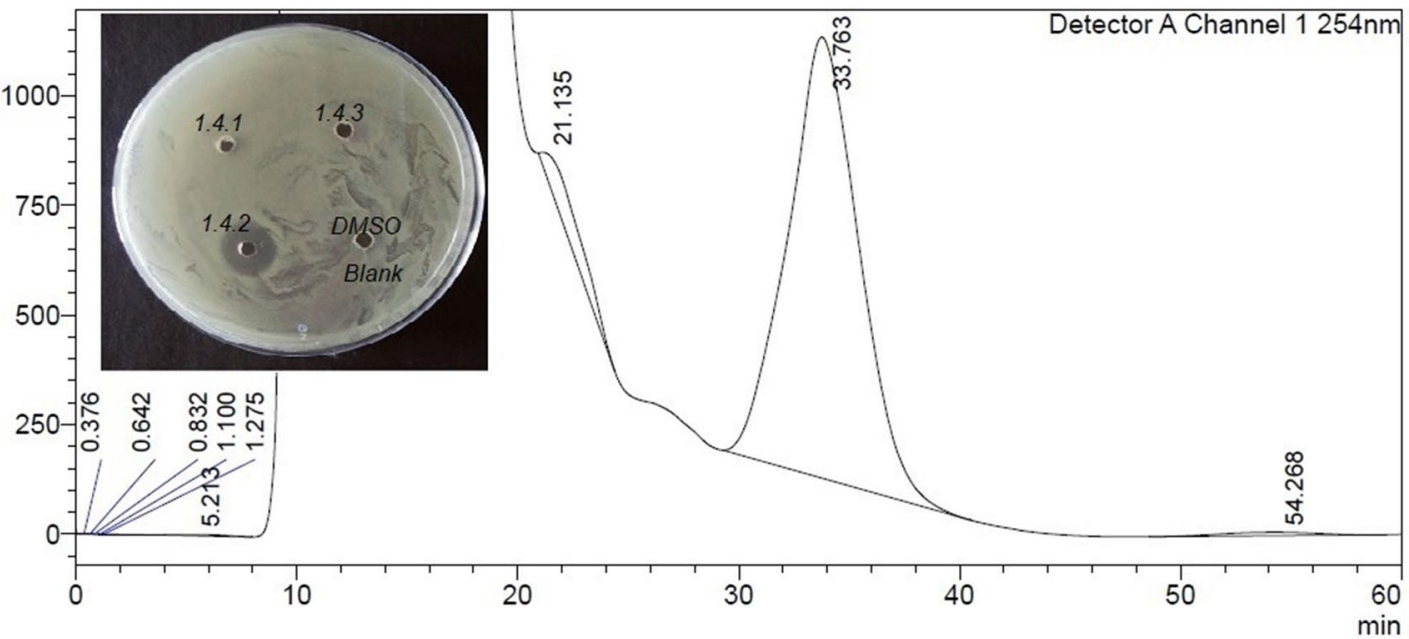

Fig. 2 Chromatogram of preparative-HPLC of fraction 1.4.2 eluted with $40 \%$ acetonitrile shows zone of inhibition

\section{$<$ Chromatogram $>$}

$\mathrm{mV}$

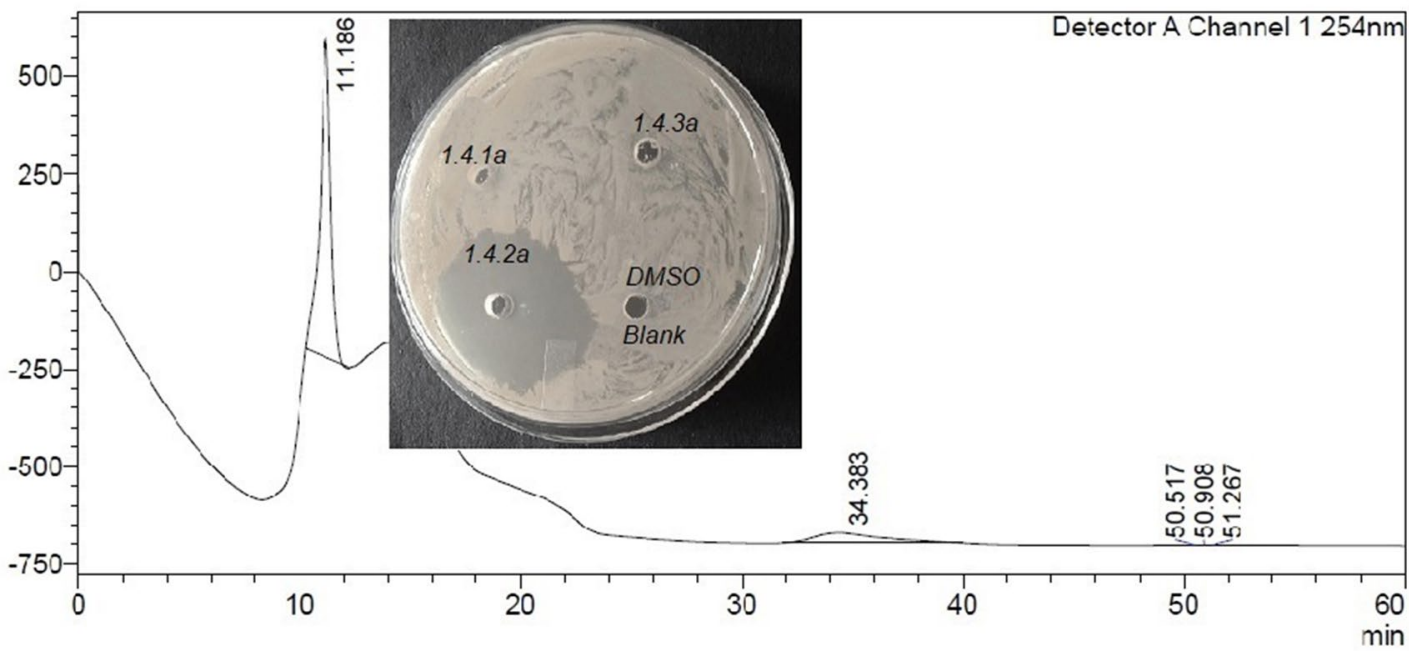

Fig. 3 Chromatogram of preparative-HPLC of fraction 1.42a eluted with $65 \%$ acetonitrile shows highest zone of inhibition

In LC-ESI tandem mass spectroscopy, as the molecules are ionized by electron impact (ESI), the peak with greatest $\mathrm{m} / \mathrm{z}$ value gives its relative mass. All other smaller peaks present around the highest peak are the molecular ions of its isotopes, therefore, its molecular weight was estimated to be $3.40287 \mathrm{KDa}$ (or $3.4 \mathrm{KDa}$ ). Antimicrobial activity of the purified bacteriocin increased by $87 \%$, specific activity by $70.5 \%$ with an increase in purification fold by $44 \%$ compared to the crude bacteriocin in cell-free supernatant (CFS) as shown Table 1. 


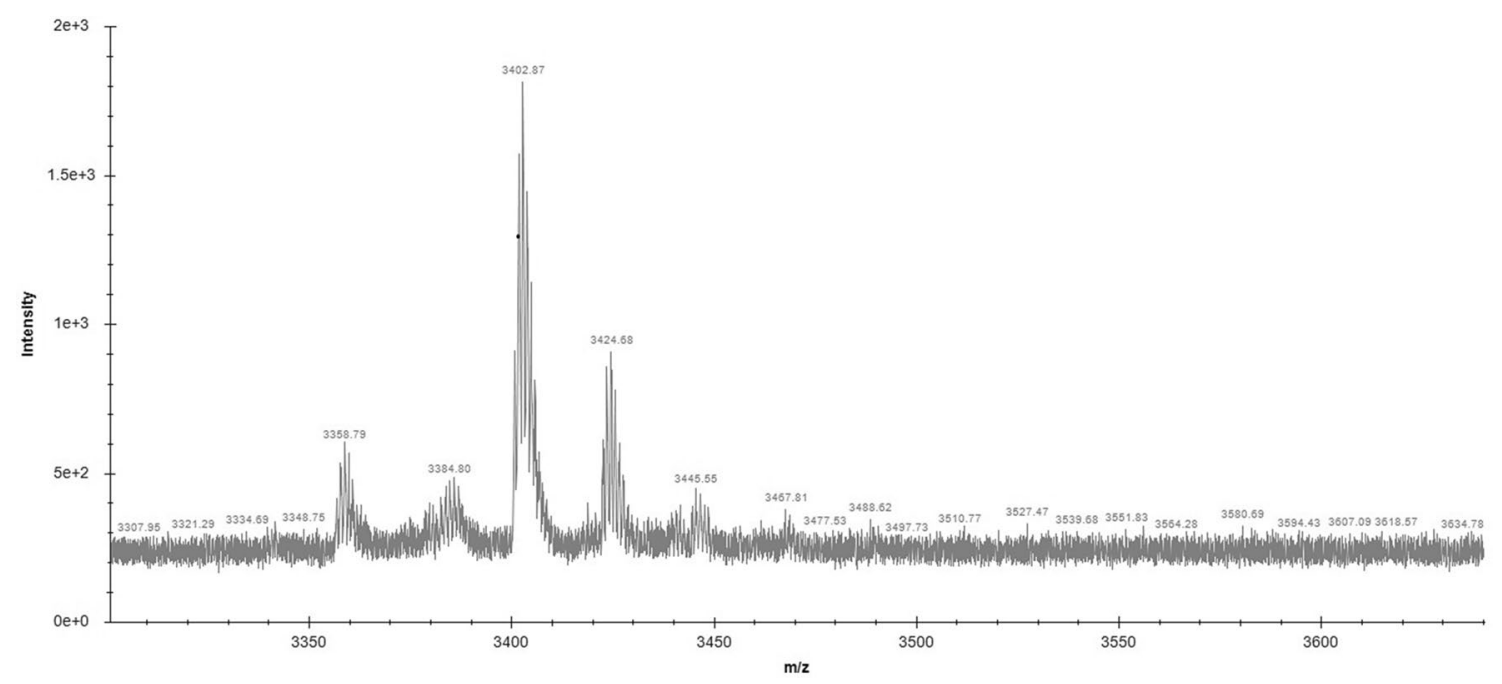

Fig. 4 Molecular mass analysis of the purified bacteriocin by liquid chromatography electron spay ionization tandem mass spectroscopy

Table 1 Purification summary of bacteriocin produced by Bacillus subtilis (MK733983)

\begin{tabular}{llllllll}
\hline Purification steps & $\begin{array}{l}\text { Volume } \\
\text { taken }(\mathrm{ml})\end{array}$ & Total protein $(\mathrm{mg})$ & Total activity (Au) & Specific activity & Recovery (\%) & $\begin{array}{l}\text { Purifica- } \\
\text { tion fold } \\
(\%)\end{array}$ & $\begin{array}{c}\text { ZOI (mm) } \\
\text { (m) }\end{array}$ \\
\hline CFS & 100 & 12,800 & 20,500 & 1.6 & 100 & 1 & $15.1 \pm 0.2$ \\
OPTN & 100 & 15,000 & 25,000 & 1.66 & 121.90 & 1.03 & $20 \pm 0.4(33 \%) \uparrow$ \\
C18 SEP-PACK & 80 & 900 & 8500 & 9.4 & 41 & 5.88 & $22 \pm 0.4(47 \%) \uparrow$ \\
RP-HPLC & 15 & 100 & 7050 & 70.5 & 34.39 & 44.06 & $28.1 \pm 0.4(87 \%) \uparrow$ \\
\hline
\end{tabular}

Values are expressed as mean $\pm \operatorname{SEM}(n=3)$; Specific activity is the ratio of activity and protein content

ZOI zone of Inhibition; IMO M. smegmatis

\section{Invitro biophysiochemical characterization}

\section{Characterization based on temperature, $\mathrm{pH}$, hydrolytic enzymes, and UV rays}

The AMP showed above $90 \%$ of antimicrobial activity at $\mathrm{pH}$ levels ranging 3.0-9.0 and temperatures up to $80^{\circ} \mathrm{C}$ but had lost activity at $121^{\circ} \mathrm{C}$. The bacteriocin was resistant to treatment with Papainase and was unaffected by salivary Amylase, also exposure to UV rays did not affect its activity up to $3 \mathrm{~h}$, as recorded in Table 2. Preservation of the bacteriocin at $-20^{\circ} \mathrm{C}$ and $4{ }^{\circ} \mathrm{C}$ for 5 months did not affect its antimicrobial activity, with their inhibition zones ranging from $28 \pm 0.12$ to $27.4 \pm 0.3$, showing $97 \%$ activity. Even though the storage at room temperatures was not effective after $24 \mathrm{~h}$, a steady maintenance of the bacteriocin activity for 5 months at refrigeration $\left(4{ }^{\circ} \mathrm{C}\right)$ temperatures is extremely valuable and economical as it does not require an ultra-cold storage facility which is both expensive and difficult to handle.

\section{Effect of chemical agents and metal ions}

The bacteriocin showed an advantageous response to the treatment with ethyl alcohol with a sharp rise in antimicrobial potency, but its activity decreased with an increase in $\mathrm{NaCl}$ concentration. It showed substantial tolerance to preservatives such as EDTA, organic solvents and most of the surfactants used in this study, except for a few like SDS and Tween 80. Metal ions like $\mathrm{Fe}^{2+}, \mathrm{Mn}^{2+}$ showed enhancement of the bacteriocin activity and it had completely lost its activity with all common protein denaturing agents that were used in this study (Table 3).

\section{Hemolytic assay}

The results of the hemolytic assay proved that the bacteriocin treatment did not affect 99.79-99.81\% (100-1000 $\mu \mathrm{g} /$ $\mathrm{mL}$ ) of erythrocytes, as clearly shown in Table 4 , signifying its non-hemolytic character. 


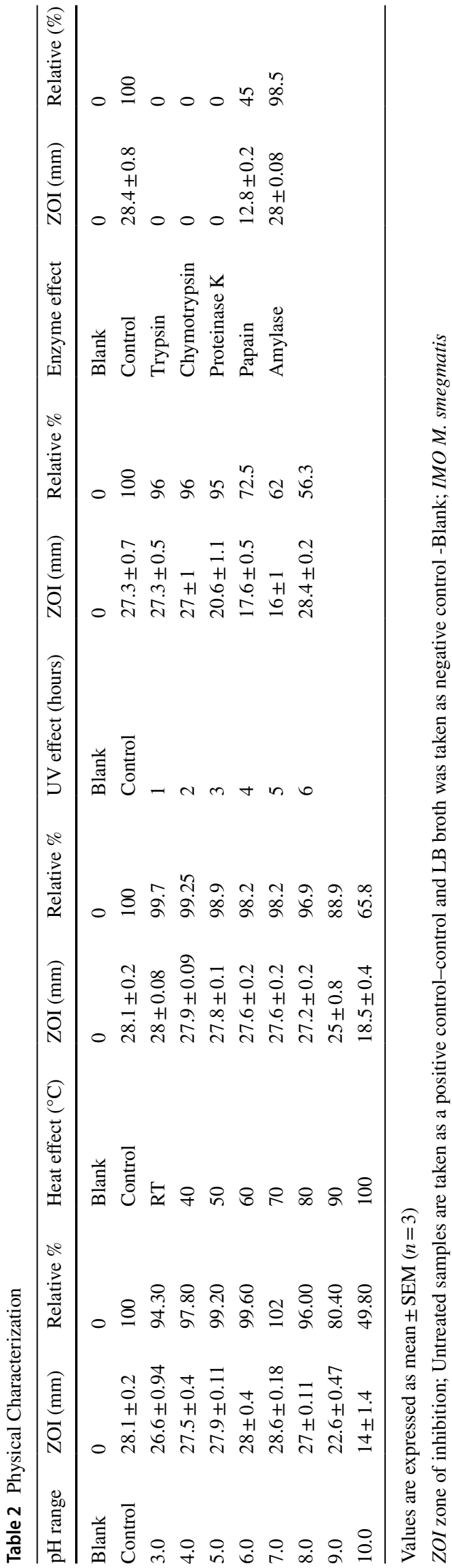

Table 3 Effect of organic solvents, surfactants, preservatives, and metal ions

\begin{tabular}{|c|c|c|}
\hline Chemical agents & $\mathrm{ZOI}(\mathrm{mm})$ & Relative \% \\
\hline Control & $28.4 \pm 0.8$ & 100 \\
\hline Blank & 0 & 0 \\
\hline DMSO & $28.2 \pm 0.2$ & 99.3 \\
\hline Methanol & $28 \pm 0.9$ & 98.9 \\
\hline Butanol & $28 \pm 0.1$ & 97.8 \\
\hline Acetone & $27.8 \pm 0.2$ & 93.3 \\
\hline Benzene & $26.5 \pm 0.5$ & 97.8 \\
\hline Propanol & $27.8 \pm 0.7$ & 98.2 \\
\hline Xylol & $27.8 \pm 0.2$ & 97.8 \\
\hline Chloroform & $27.6 \pm 0.5$ & 97.1 \\
\hline EDTA & $27.4 \pm 0.5$ & 96.4 \\
\hline SDS & $16.25 \pm 0.5$ & 57.21 \\
\hline Triton X 100 & $27.8 \pm 0.7$ & 97.8 \\
\hline Tween 20 & $23.7 \pm 0.2$ & 98.38 \\
\hline Tween 80 & $23.7 \pm 0.2$ & 75.7 \\
\hline sulfobetaine 14 & $27.1 \pm 1.04$ & 95.42 \\
\hline Sodium deoxycholate & $27.6 \pm 0.7$ & 97 \\
\hline Sodium citrate & $26.3 \pm 0.5$ & 92.6 \\
\hline Sodium tungstate & $26.3 \pm 1$ & 92.5 \\
\hline $\mathrm{KCl}$ & $24.1 \pm 0.76$ & 84.85 \\
\hline $\mathrm{CaCl}_{2}$ & $21.6 \pm 1.5$ & 75 \\
\hline $\mathrm{FeSO}_{4}$ & $32.5 \pm 0.5$ & 114.4 \\
\hline $\mathrm{ZnSO}_{4}$ & $18.4 \pm 0.5$ & 64.7 \\
\hline $\mathrm{CuCl}_{2}$ & 0 & 0 \\
\hline $\mathrm{MgSO}_{4}$ & $15.6 \pm 0.5$ & 54.9 \\
\hline $\mathrm{MnSO}_{4}$ & $30 \pm 1$ & 105.6 \\
\hline
\end{tabular}

Values are expressed as mean $\pm \operatorname{SEM}(n=3)$

$\mathrm{ZOI}$ zone of inhibition; Untreated samples are taken as a positive control-control and LB broth was taken as negative control-Blank; IMO M. smegmatis

\section{Inhibition spectrum and minimal inhibitory concentration (MIC)}

The RP-HPLC purified bacteriocin (PB) demonstrated improved growth inhibition against Gram positive and negative bacteria as shown in Table 5. Highest increase in the bacteriocin activity was observed in S. aureus (Gram positive) and $P$. aeruginosa (Gram negative) with $60 \%$ and $39.9 \%$, respectively, compared to the potency of $\mathrm{C}_{18}$ SEPPACK partially purified bacteriocin (PPB).

\section{Mechanism of action}

Several topographical variations were spotted through FESEM analysis in the indicator cells treated with bacteriocin. Some of the prominent observations made in the bacteriocin treated $S$. aureus cells (SA) are irregular cell surfaces (a), flatter cells (b), accumulation of cell debris 
Table 4 Hemolytic assay

\begin{tabular}{|c|c|c|c|c|c|c|c|c|}
\hline Well No & $\begin{array}{l}\text { Bacteriocin-100 } \mu \mathrm{g} / \\
\mathrm{mL}\end{array}$ & $\mathrm{H} \%$ & $\begin{array}{l}\text { Bacteriocin- } 250 \mu \mathrm{g} / \\
\mathrm{mL}\end{array}$ & $\mathrm{H} \%$ & $\begin{array}{l}\text { Bacteriocin-500 } \mu \mathrm{g} / \\
\mathrm{mL}\end{array}$ & $\mathrm{H} \%$ & $\begin{array}{l}\text { Bacteriocin-1000 } \mu \mathrm{g} / \\
\mathrm{mL}\end{array}$ & $\mathrm{H} \%$ \\
\hline 1 & $0.0009 \pm 0.000003$ & 0.21 & $0.002 \pm 0.0003$ & 0.51 & $0.0051 \pm 0.0007$ & 1.35 & $0.0087 \pm 0.0004$ & 2.19 \\
\hline 2 & $0.0007 \pm 0.0000011$ & 0.15 & $0.0014 \pm 0.0003$ & 0.24 & $0.0034 \pm 0.0005$ & 0.9 & $0.0059 \pm 0.0007$ & 1.48 \\
\hline 3 & $0.0005 \pm 0.0000031$ & 0.1 & $0.001 \pm 0.0001$ & 0.21 & $0.0024 \pm 0.0003$ & 0.63 & $0.005 \pm 0.0005$ & 1.24 \\
\hline 4 & $0.0003 \pm 0.000004$ & 0.15 & $0.0005 \pm 0.000004$ & 0.1 & $0.0015 \pm 0.0002$ & 0.38 & $0.004 \pm 0.0006$ & 0.99 \\
\hline 5 & $0.0002 \pm 0.0000033$ & $<0.05$ & $0.0003 \pm 0.000002$ & $<0.05$ & $0.0009 \pm 0.000009$ & 0.21 & $0.0019 \pm 0.0003$ & 0.45 \\
\hline 6 & $0.00018 \pm 0.0000017$ & $<0.05$ & $0.00015 \pm 0.0000047$ & $<0.05$ & $0.0004 \pm 0.000007$ & 0.07 & $0.0006 \pm 0.0002$ & 0.11 \\
\hline 7 & $0.00012 \pm 0.0000016$ & $<0.05$ & $0.00013 \pm 0.00003$ & $<0.05$ & $0.00016 \pm 0.000004$ & $<0.05$ & $0.00033 \pm 0.000007$ & $<0.05$ \\
\hline 8 & $0.00012 \pm 0.0000017$ & $<0.05$ & $0.00012 \pm 0.000002$ & $<0.05$ & $0.00013 \pm 0.000003$ & $<0.05$ & $0.0002 \pm 0.000002$ & $<0.05$ \\
\hline 9 & $0.00012 \pm 0.0000018$ & $<0.05$ & $0.0001 \pm 0.0000021$ & $<0.05$ & $0.00012 \pm 0.000001$ & $<0.05$ & $0.0001 \pm 0.00003$ & $<0.05$ \\
\hline 10 & $0.00012 \pm 0.0000019$ & $<0.05$ & $0.0001 \pm 0.0000009$ & $<0.05$ & $0.0001 \pm 0.0000009$ & $<0.05$ & $0.0001 \pm 0.000001$ & $<0.05$ \\
\hline 11 & 0.0001 & 0 & 0.0001 & 0 & 0.0001 & 0 & 0.0001 & 0 \\
\hline 12 & $0.36 \pm 0.02$ & 100 & $0.36 \pm 0.02$ & 100 & $0.36 \pm 0.02$ & 100 & $0.39 \pm 0.035$ & 100 \\
\hline
\end{tabular}

Values are expressed as mean $\pm \operatorname{SEM}(n=4)$

Table 5 Inhibition Spectrum and Minimal Inhibitory Concentration (MIC)

\begin{tabular}{lllll}
\hline $\begin{array}{l}\text { Indicator microorgan- } \\
\text { isms (IMO) }\end{array}$ & MIC (PPB) & MIC (PB) & PPB ZOI (mm) & PB ZOI (mm) \\
\hline M. smegmatis & $0.34 \pm 0.005$ & $0.275 \pm 0.02$ & $22.25 \pm 0.25$ & $28.48 \pm 0.1$ \\
S. aureus & $0.33 \pm 0.02$ & $0.225 \pm 0.03$ & $20.75 \pm 0.25$ & $32.5 \pm 0.5$ \\
P. aeruginosa & $0.6 \pm 0.02$ & $0.375 \pm 0.03$ & $26.3 \pm 0.12$ & $36.8 \pm 0.6$ \\
K. pneumoniae & $0.76 \pm 0.02$ & $0.55 \pm 0.07$ & $24.25 \pm 0.25$ & $31.8 \pm 0.6$ \\
E. coli & $0.73 \pm 0.02$ & $0.525 \pm 0.1$ & $14.75 \pm 0.25$ & $19.6 \pm 0.4$ \\
C. violaceum & $0.76 \pm 0.05$ & $0.45 \pm 0.07$ & $12.25 \pm 0.25$ & $14.5 \pm 0.4$ \\
\hline
\end{tabular}

Values are expressed as mean $\pm \operatorname{SEM}(n=3)$

$M I C$ minimal inhibitory concentration; $P B$ purified bacteriocin; $P P B$ partially purified bacteriocin; $Z O I$ zone of inhibition (c), and prominent pore formation (d). On the other hand, $P$. aeruginosa (PA) treated cells also showed noticeably shortened cells (a), swollen cells (b), and cells displaying pore formation (c), as compared to the topography of untreated cells (Fig. 5). The bacteriocin treated cells visibly seemed to be damaged, disfigured, and lysed. The pores seen in cells of both gram positive and negative bacteria suggest a bactericidal impact and the cell death might have occurred due to cell constituent's leakage.

\section{Discussion}

A potential bacteriocin isolated as a transient endophyte from Bacillus subtilis (MK733983) was elucidated and its characteristics were evaluated in this study. PreparativeRP-HPLC was used for the benefit of effective purification, quantification, and categorical characterization of the bacteriocin (Aurea et al. 2011, 2014). Studies have shown that the antibacterial activity depends on hydrophobic interaction between microbes and AMPs. In agreement with the same, it was rational that the elution with $65 \%$ acetonitrile can fractionate hydrophobic moieties more efficiently than with $40 \%$ of acetonitrile. This could be one plausible reason for the higher antimicrobial activity of RP-HPLC fraction eluted with $65 \%$ acetonitrile (Gao et al. 1991).

The proteinaceous nature of this bacteriocin was confirmed as it entirely lost activity with proteolytic enzymes, validating its position as GRAS (generally accepted as safe) peptide. Partial impediment in antimicrobial activity by Papainase indicated that the antimicrobial peptide may have had Papain-resistant components. It showed notable features like tolerance to organic solvents, anionic detergents (sulfobetaine 14), zwitterionic detergents (sodium deoxycholate), synergistic action with ethyl alcohol and metal ions $\left(\mathrm{Fe}^{2+}, \mathrm{Mn}^{2+}\right.$. Additionally, thermostability and a wide-ranging $\mathrm{pH}$ tolerance expand its possibilities as a bio-preservative and for other industrial applications (Hammami et al. 2009). Several AMPs have 


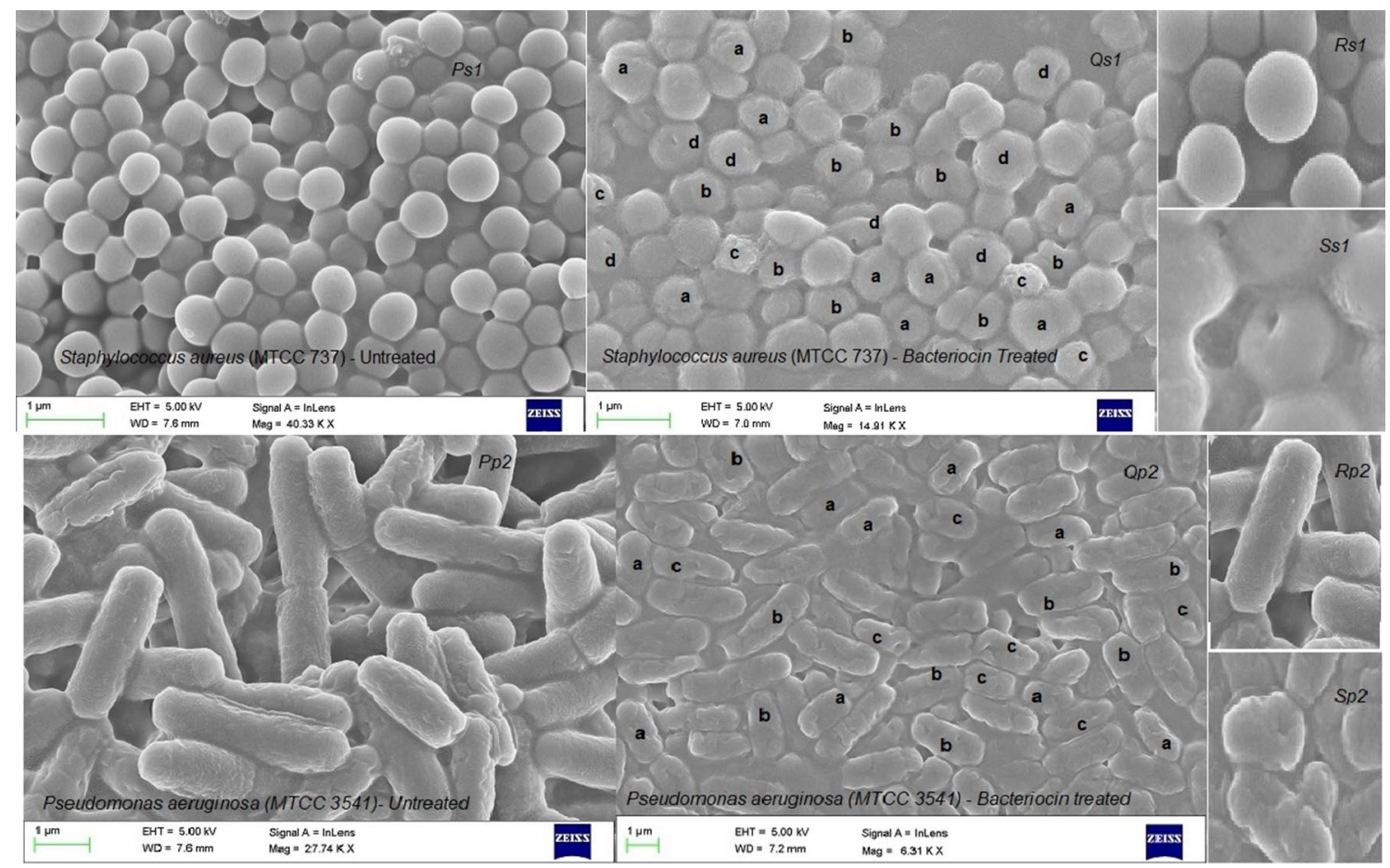

Fig. 5 FESEM images of Staphylococcus aureus (MTCC 737) cells treated with purified bacteriocin. $\mathrm{Ps}_{1}$-Untreated cells (control); $\mathrm{Qs}_{1}$-Bacteriocin treated cells: a-irregular cell surfaces; b-flattened cells; c-cell debris; d-Visual pores. Rs $\mathrm{R}_{1}$-Magnified image of an untreated cell and $\mathrm{Ss}_{1}$-Magnified image of the treated cell. FESEM

recorded hemolysis as a critical limitation and so, they were employed for topical therapies to avoid systemic adverse effects (Pfalzgraff et al. 2018). The bacteriocin presented in this study has shown non-hemolytic nature, enhancing its curative options. The bacteriocin showed excellent tolerance ( $>95 \%)$ to specified biological detergents such as Sulfobetaine-14 and Sodium deoxycholate. Sulfobetaine-14 is widely used in hair conditioners, contact lens solutions and in the purification of proteins. On the other hand, Sodium deoxycholate is often used as a biological detergent and for cytolytic medications. Commercial value of the biological surfactants with added antiinfective agents (like the mentioned bacteriocin) can both be profitable and of therapeutic gain.

Antimicrobial peptides typically tend to inhibit taxonomically related strains but the bacteriocin emphasized in this study displayed broad inhibition spectrum. It was uniquely similar to Subtilein (Park et al. 2002), Thuricin 17 (Gray et al. 2006), Cerein 8A (Bizani et al. 2005), Gas 101 (Sharma et al. 2018) through its antagonistic activity against $S$. aureus, $P$. aeruginosa and E. coli. Besides, it also showed effective inhibition of M. smegmatis, K. pneumoniae and $C$. violaceum. The bacteriocin showed maximum antibacterial effect towards critically prioritized standard microbes and analogues suuucch as $S$. aureus, M. smegmatis, $P$. images of Pseudomonas aeruginosa (MTCC 3541) cells treated with purified bacteriocin. $\mathrm{Pp}_{2}$-Untreated cells (control); $\mathrm{Qp}_{2}$-Bacteriocin treated cells, a shortened cells; $\mathbf{b}$ swollen cells; $\mathbf{c}$ visual Pores in cell. $\mathrm{Rp}_{2}$-Magnified image of an untreated cell and $\mathrm{Sp}_{2}$-Magnified image of treated cell

aeruginosa followed by others. The rationale for higher bacteriocin dosage to inhibit gram-negative strains might account on their taxonomical differences.

Nearly all studies performed on C. violaceum are mostly committed to its quorum sensing ability and other biotechnological purposes. However, its first clinical risk reported by Bottieau et al. (2014) capable of eliciting serious bacteremia was alarming. This infection was reported to be intimidating as it spreads through the skin or respiratory system with fatality rate exceeding $50 \%$. Currently, it is reported as an emerging pathogen (Batista and Neto 2017) and the bacteriocin's ability to inhibit $C$. violaceum must be further explored. Likewise, the bacteriocin might be antagonistic to various other microbes with analogous quorum sensing strategies resembling $C$. violaceum and it requires further research. Most pathogens come up with compelling quorum sensing mechanisms, significant for biofilm development as reported in ESKAPE pathogens (Enterococcus faecium, Staphylococcus aureus, Klebsiella pneumoniae, Acinetobacter baumannii, Pseudomonas aeruginosa, and Enterobacter spp.). Inhibition of some standard strains belonging to ESKAPE list reiterates the bacteriocin's prominence and its forthcoming propensity for biofilm inhibition.

$M$. tuberculosis causes Tuberculosis (TB) and the soaring global TB drug resistance is frightening. TB is the leading 
cause of death in most immunocompromised individuals. Potential drugs and novel vaccines will be required to achieve the targets set in 'The End TB Strategy' by WHO (Tiberi et al. 2018). AMPs as potential antimycobacterial agents or drug candidates are relatively less explored (Sivaraj et al. 2018; Aguilar-Perez et al. 2018 and Sosunov et al. 2007). Invention and Development of novel antitubercular drugs and vaccines have become extremely challenging and causes for its shortage are numerous. One of the reasons for this paucity is also due to the impenetrable, composite cell walls of Mycobacterium species. It consists of a hydrophobic mycolate layer bound to peptidoglycan layer with polysaccharides and arabinogalactans. Thus, the selected drug agents must target its cell wall components with diverse strategies. The bacteriocin staged in this research showed bactericidal effect on $M$. smegmatis, a widely credited surrogate for M. tuberculosis (Agrawal et al. 2015; Li et al. 2004). Further the in-vivo investigations of this bacteriocin on M. tuberculosis and its resistant strains will be essential to explicate its efficacy. Further, the bactericidal action with prominent pore formation was seen in both gram positive and negative bacteria accord with toroidal pore model described by Le et al. (2017). The model illustrates that the bacteriocin interaction with cell membranes disturb its electrochemical potential. It forces the cell membrane to aggregate peptide monomers and lipid moieties to fold inward to form pores. Further, permeation of proteins and other larger molecules through these pores, destroy cell morphology and cell membranes ultimately resulting in cell death.

Many studies report antiviral drug resistance for respiratory, sexually transmitted, and enteric viruses and there is a pressing need for effective antiviral agents. Lange-Starke et al. (2014) registered an antiviral peptide (AVP) effective on murine norovirus $\mathrm{S} 99$ (MNV), influenza A virus A/ WSN/ 33 (H1N1), Newcastle disease virus Montana (NDV) and feline herpesvirus KS 285 (FHV). Wang et al. (2017) documented effective inhibition of transmissible gastroenteritis virus by surfactin. Silva et al. (2014) stated an AMP from $B$. subtilis, $\mathrm{P} 34$ for inhibiting canine adenovirus type 2 (CAV-2), canine coronavirus $(\mathrm{CCoV})$, canine distemper virus (CDV), canine parvovirus type $2(\mathrm{CPV}-2)$ and equine arteritis virus (EAV). Starosila et al. (2017) and Peng et al. (2019) reported AVPs for porcine epidemic diarrhea virus. Kassaa et al. (2014) described the effect of LAB probiotics against viral infections. Search for AVPs from Bacillus genus is an emerging frontier and future assessment of the antiviral, antifungal, antiparasitic and antitumor potential of the presented bacteriocin is essential.

As per our knowledge, the present study is presenting a unique and potential Ethno-Phyto-microbiome originated bacteriocin. It has effective antimycobacterial activity and is antibacterial towards certain vital bacterial standard strains.
It is non-hemolytic with many beneficial biophysiochemical features and an effective mechanism of action.

\section{Conclusion}

AMR is an evolved health hazard with impoverished drug remedies in the modern world. Experts globally warn that we are on the brink of a disaster with increasing emergence of novel infections and resistant microbes down with a dearth of effective drugs and vaccines. The ongoing pandemic by SARSCov-2 virus (2020) is a wake-up call to brisk the discovery and development of potential drugs and vaccines. This deadly viral infection has brought the entire human population to a halt waiting for novel antimicrobial agents. Adding to this, healthcare professionals globally also predict that the estimated economic burden of resistance due to E. coli, K. pneumoniae, $S$. aureus, Tuberculosis, HIV, and malaria together will soon reach a worst-case scenario. We urgently require immediate effective measures and novel antimicrobial agents with diverse strategies. Though many approaches are being developed to treat microbial infections, antimicrobial peptides are promising alternatives. AMPs are drawing attention as potential drug candidates, as they can kill the resistant microbes with precise selective toxicity and without developing resistance. Many AMPs show negligible host cytotoxicity, can inhibit evolved biofilms targeting their stress response and can synergize with several antibiotics. The bacteriocin presented in this investigation has justified its broad inhibition spectrum against critical strains of Gram positive, Gram negative and TB pathogen analogue. Further in vivo studies will contribute to its development as a precursor for the development of promising additional anti-mycobacterial/anti-bacterial drugs and other application prospects.

Supplementary Information The online version contains supplementary material available at https://doi.org/10.1007/s00203-020-02173-7.

Acknowledgements The authors wish to express their sincere gratitude and recognition for assistance from Dr. Solomon (with HPLC) and Mr. Regan Charles (with SEM analysis) of Department of Biotechnology, Jain (Deemed to-be) University.

Author contributions The authors have contributed to designing this study, performed research, analyzed data, and wrote the article.

Funding This research did not receive any specific grant from funding agencies in the public, commercial, or not-for-profit sectors.

Data availability All the data, text and results presented in this publication are authors own. The datasets generated during and/or analyzed during the current study are available from the corresponding author on reasonable request.

Code availability Not Applicable. 


\section{Compliance with ethical standards}

Conflict of interest The authors declare no conflict of interest.

Ethical approval Not Applicable.

Consent to participate The authors give their consent to participate.

Consent for publication The authors give their consent for publication.

\section{References}

Afsar T, Razak S, Khan MR, Mawash S, Almajwa A, Shabir M, Haq IU (2016) Evaluation of antioxidant, anti-hemolytic and anticancer activity of various solvent extracts of Acacia hydaspica R. Parker aerial parts. BMC Complement Altern Med 16:258. https://doi.org/10.1186/s12906-016-1240-8

Agrawal P, Miryala S, Varshney U (2015) Use of Mycobacterium smegmatis deficient in ADP ribosyl transferase as surrogate for Mycobacterium tuberculosis in drug testing and mutation analysis. PLoS ONE 10(4):e0122076. https://doi.org/10.1371/ journal.pone.0122076

Aguilar-Pérez C, Gracia B, Rodrigues L, Vitoria A, Cebrián R, Deboosère N, Song O-R, Brodin P, Maqueda M, Aínsa JA (2018) Synergy between circular bacteriocin AS-48 and ethambutol against Mycobacterium tuberculosis. Antimicrob Agents Chemother 62:e00359-e418. https://doi.org/10.1128/ AAC.00359-18

Anand TP, Bhat AW, Shouche YS, Roy U, Siddharth J, Sarma SP (2005) Antimicrobial activity of marine bacteria associated with sponges from the waters off the coast of South East India. Microbiol Res 161(2006):252-262. https://doi.org/10.1016/j.micre s.2005.09.002

Aurea AE, Tanh LC, Mai LN, Philippe D (2011) Reverse-high performance liquid chromatography mechanism explained by polarization of stationary phase. CheM 1:62-79. https://doi.org/10.5618/ chem.2011.v1.n1.8

Aurea AE, Roya S, Manolis NR, Philippe D (2014) An alternative to trial and error methodology in solid phase extraction: an original automated solid phase extraction procedure for analyzing PAHs and PAH-derivatives in soot. RSC Adv 4:33636. https://doi. org/10.1039/c4ra03214d

Balouiri M, Sadiki M, Ibnsouda SK (2016) Methods for in vitro evaluating antimicrobial activity: a review. J Pharmaceut Anal 6(2):71-79

Batista JH, da Neto JFN (2017) Chromobacterium violaceum pathogenicity: updates and insights from genome sequencing of novel chromobacterium species. Front Microbiol 8:2213. https://doi. org/10.3389/fmicb.2017.02213

Bizani D, Brandelli A (2002) Characterization of a bacteriocin produced by a newly isolated Bacillus sp. Strain 8 A. J Appl Microbiol 93(3):512-519. https://doi.org/10.1046/j.1365-2672.2002.01720.x

Bizani D, Motta AS, Morrissy JA, Terra R, Souto AA, Brandelli A (2005) Antibacterial activity of cerein $8 \mathrm{~A}$, a bacteriocin-like peptide produced by Bacillus cereus. Int Microbiol 8:125-131

Boelaert M, Jacobs J (2014) Fatal chromobacterium violaceum bacteraemia in rural Bandundu, Democratic Republic of the Congo. New Microbes New Infect 3:21-23. https://doi.org/10.1016/j. nmni.2014.10.007

Cita YP, Suhermanto A, Radjasa OK, Sudharmono P (2017) Antibacterial activity of marine bacteria isolated from sponge Xestospongia testudinaria from Sorong. Papua Asian Pac J Trop Biomed 7(5):450-454. https://doi.org/10.1016/j.apjtb.2017.01.024
Gao FH, Abee T, Konings WN (1991) Mechanism of action of the peptide antibiotic nisin in liposomes and cytochrome c oxidasecontaining proteoliposomes. Appl Environ Microbiol 57(8):2164 2170. https://doi.org/10.1128/AEM.57.8.2164-2170.1991

Ge J, Sun Y, Xin X, Wang Y, Ping W (2016) Purification and partial characterization of a novel bacteriocin synthesized by Lactobacillus paracasei HD1-7 isolated from Chinese Sauerkraut juice. Sci Rep 6:19366. https://doi.org/10.1038/srep19366

Gray EJ, Lee KD, Souleimanov AM, Falco MRD, Zhou X, Ly A, Charles TC, Driscoll BT, Smith DL (2006) A novel bacteriocin, thuricin 17, produced by plant growth promoting rhizobacteria strain Bacillus thuringiensis NEB17: isolation and classification. J Appl Microbiol 100(3):545-554. https://doi.org/10.111 1/j.1365-2672.2006.02822.x

Gutsmann T (2016) Interaction between antimicrobial peptides and mycobacteria. Biochem Biophys Acta 1858:1034-1043. https:// doi.org/10.1016/j.bbamem.2016.01.031

Hammami RA, Jaouadi B, Rebai A, Nesme X (2009) Optimization and biochemical characterization of a bacteriocin from a newly isolated Bacillus subtilis strain 14B for biocontrol of Agrobacterium spp. Strains Lett Appl Microbiol 48(2):253-260. https://doi. org/10.1111/j.1472-765X.2008.02524.x

Kassaa A, Hober I, Hamze D, Chihib NE, Drider D (2014) Antiviral potential of lactic acid bacteria and their bacteriocins. Probiotics Antimicrob Prot 6:177-185. https://doi.org/10.1007/s1260 2-014-9162-6

Lange-Starke A, Petereit A, Truyen U, Braun PG, Fehlhaber K, Albert T (2014) Antiviral potential of selected starter cultures, bacteriocins and D, L-Lactic Acid. Food Environ Virol 6(1):42-47. https ://doi.org/10.1007/s12560-013-9135-z

Le CF, Fang CM, Sekaran SD (2017) Intracellular targeting mechanisms by antimicrobial peptides. Antimicrob Agents Chemother 61:e02340-e2416. https://doi.org/10.1128/AAC.02340-16

Lee SG, Chang HG (2018) Purification and characterization of mejucin, a new bacteriocin produced by Bacillus subtilis SN7. LWT Food Sci Technol 87:815. https://doi.org/10.1016/j.lwt.2017.08.044

Li XZ, Li Z, Hiroshi N (2004) Efflux pump-mediated intrinsic drug resistance in Mycobacterium smegmatis. Antimicrob Agents Chemother 48(7):2415-2423. https://doi.org/10.1128/ AAC.48.7.2415-2423.2004

Lowry OH, Rosebrough NJ, Farr AL, Randall RJ (1951) Protein measurement with the Folin phenol reagent. J Biol Chem 193(1):265-275

Malini M, Savitha J (2012) Heat stable bacteriocin from Lactobacillus paracasei subsp. tolerans isolated from locally available cheese: an in vitro study. J Biotechnol Pharm Res 3(2):28-41

Naafs MAB (2018) The antimicrobial peptides: ready for clinical trials? Biomed J Sci Technol Res. https://doi.org/10.26717/BJSTR .2018 .07 .001536

Park YS, Yang YJ, Kim YB, Hong JH, Lee C (2002) Characterization of subtilein, a bacteriocin from Bacillus subtilis CAU131 (KCCM 10257). J Microbiol Biotechnol 12(2):228-234

Peng JY, Horng YB, Wu CH, Chang CY, Tsai PS, Jeng CR, Cheng YH, Chang HW (2019) Evaluation of antiviral activity of Bacillus licheniformis-fermented products against porcine epidemic diarrhea virus. AMB Express 9(1):191. https://doi.org/10.1186/ s13568-019-0916-0

Pfalzgraff A, Brandenburg K, Weindl G (2018) Antimicrobial peptides and their therapeutic potential for bacterial skin infections and wounds. Front Pharmacol 9:281. https://doi.org/10.3389/fphar .2018 .00281

Ramya R, Chalasani AG, Lal R, Roy U (2014) A broad-spectrum antimicrobial activity of Bacillus subtilis RLID 12.1. Sci World J. https://doi.org/10.1155/2014/968487

Santhi SS, Aranganathan V (2019) Bioprospecting of some ethnomedicinal plants for potential antimycobacterial bacteriocin 
like inhibitory substances (BLIS). Explor Anim Med Res 9(2):180-187

Sharma G, Dang S, Gupta S, Gabrani R (2018) Antibacterial activity, cytotoxicity, and the mechanism of action of bacteriocin from Bacillus subtilis GAS101. Med Princ Pract 27(2):186-192. https ://doi.org/10.1159/000487306

Silva DS, Castro CC, Silva FS, Santanna V, Vargas GD, Lima MD, Fischer G, Brandelli A, Motta AS, Hübner SO (2014) Antiviral activity of a Bacillus sp. P34 peptide against pathogenic viruses of domestic animals. Braz J Microbiol 45(3):1089-1094

Sivaraj A, Sundar R, Manikkam R, Parthasarathy K, Rani U, Vanaja K (2018) Potential applications of lactic acid bacteria and bacteriocins in antimycobacterial therapy. Asian Pac J Trop Med 11(8):453-459. https://doi.org/10.4103/1995-7645.240080

Sohail M, Sultana Q, Rasool K, Sarwar S, Basit A, Khalid M (2015) Bacteremia prediction by inflammatory factors and recent trend in drug resistance of bacteria isolated from blood stream infection. J Inf Mol Biol 3(3):75-80. https://doi.org/10.14737/journ al.jimb/2015/3.3.75.80

Sosunov V, Mischenko V, Eruslanov B, Svetoch E, Shakina Y, Stern N, Majorov K, Sorokoumova G, Selishcheva A, Apt A (2007) Antimycobacterial activity of bacteriocins and their complexes with liposomes. J Antimicrob Chemother 59(5):919-925. https:// doi.org/10.1093/jac/dkm053

Soto PF (2014) Purification and characterization of an antimicrobial peptide produced by Bacillus sp. strain P7. Dissertation, University of Manchester.

Starosila D, Rybalko S, Varbanetz L, Ivanskaya N, Sorokulova I (2017) Anti-influenza activity of a Bacillus subtilis probiotic strain. Antimicrob Agents Chemother 61:e00539-e617. https:// doi.org/10.1128/AAC.00539-17

Tagg JR, McGiven AR (1971) Assay system for bacteriocins. Appl Microbiol 21(5):943
Tiberi S, Muñoz-Torrico M, Duarte R, Dalcolmo M, D’Ambrosio L (2018) Migliori GB (2017) New drugs and perspectives for new anti-tuberculosis regimens. Pulmonology 24(2):86-98. https://doi. org/10.1016/j.rppnen.10.009

Wang X, Hu W, Zhu L, Yang Q (2017) Bacillus subtilis and surfactin inhibit the transmissible gastroenteritis virus from entering the intestinal epithelial cells. Biosci Rep 37(2):BSR20170082. https ://doi.org/10.1042/BSR20170082

WHO (2017) Antibacterial agents in clinical development: an analysis of the antibacterial clinical development pipeline, including tuberculosis. Geneva: World Health Organization (WHO/EMP/ IAU/2017.12). Licence: CC BY-NC-SA 3.0 IGO.CIP data are available at http://apps.who.int/iris. Accessed 20 Feb 2018

WHO (2020) Report https://www.who.int/news-room/fact-sheets/detai 1/antimicrobial-resistance. Accessed 31 July 2020

Wolcott RD, Ehrlich GD (2008) Biofilms and chronic infections. JAMA 299(22):2682-2684. https://doi.org/10.1001/jama.299.22.2682

Wu J, Abbas HMK, Li J, Yuan Y, Liu Y, Wang G, Dong W (2020) Cell membrane-interrupting antimicrobial peptides from Isatis indigotica fortune isolated by a Bacillus subtilis expression system. Biomolecules. https://doi.org/10.3390/biom10010030

Zhang J, Yang Y, Yang H, Bu Y, Yi H, Zhang L, Han X, Ai L (2018) Purification and partial characterization of bacteriocin Lac-B23, a novel bacteriocin production by Lactobacillus plantarum J23, isolated from Chinese traditional fermented milk. Front Microbiol 9:2165. https://doi.org/10.3389/fmicb.2018.02165

Publisher's Note Springer Nature remains neutral with regard to jurisdictional claims in published maps and institutional affiliations. 